\title{
Experimental Study on Performance of Recycled Concrete Aggregate as Course Aggregate and Silica Fume As Partial Replacement for Cement with Different Water Binder Ratio
}

\author{
K.M.Gopalakrishnan ${ }^{1}$, G.Nithyaprakash ${ }^{2}$, E.Sivaraj $^{3}$, Dr.R.Murugesan ${ }^{4} 1 \& 2$ \\ Assistant Professor, Erode Sengunthar Engineering College,3-Sivaraj Timbers\& 4- Professor, IRTT, Erode
}

\subsection{INTRODUCTION:}

\section{Chapter}

One of the construction sector's major contributions to the preservation of the environment and sustainable development is the reuse and recycling of the waste materials it generates (reducing, reusing, recycling and regenerating the residues that originate the constructive activity). One way of achieving this is to introduce recycled aggregates from construction and demolition debris and rubble into the production processes. This increases the life cycle of these materials, thereby reducing the amount of waste dumping and natural resource extraction.

\subsection{ADVANTAGES OF RECYCLED CONCRETE AGGREGATE}

There are many advantages through using the recycled aggregate. The advantages that occur through usage of recycled aggregate are

\section{Environmental Gain}

2. Save Energy

3. Cost

1.3 SILICA FUME IN CONCRETE:

The American concrete institute (ACI) defines Silica fume as, "Very non-crystalline silica produced in electric furnaces as a by product of the production of elemental silicon alloys containing silicon" Silica fume usually referred as
1) Condensed Silica Fume
2) Micro Silica
3) Volatized Silica.

\subsection{SCOPE OF THE INVESTIGATION:}

$>$ To determine the strength characteristic of Recycled Concrete Aggregate and to determine the optimum level of replacement of Natural Coarse Aggregate by Recycled Concrete Aggregate

$>$ To determine the strength characteristic of concrete by adding the Silica fume as a partial replacement for different water- binder ratio and to conduct the durability studies.

\subsection{PROPERTIES OF MATERIALS}

\section{Chapter}

\subsubsection{INTRODUCTION}

Experiments were conducted to study the physical and mechanical properties of materials such as Cement, Sand, Natural Coarse Aggregate and Recycled Concrete Aggregate (NCA \& RCA) the results are shown in Table 2.1 to 2.4 .

\subsubsection{SILICA FUME}

Table - 2.1 Chemical Properties of Silica fume

\begin{tabular}{|c|c|c|c|}
\hline Constituent & Percentage (\%) & Constituent & Percentage (\%) \\
\hline $\mathrm{SiO}_{2}$ & $90-96$ & $\mathrm{Na}_{2} \mathrm{O}$ & $0.2-0.7$ \\
\hline $\mathrm{Al}_{2} \mathrm{O}_{3}$ & $0.5-0.8$ & $\mathrm{~K}_{2} \mathrm{O}$ & $0.4-1.0$ \\
\hline $\mathrm{MgO}$ & $0.5-1.5$ & $\mathrm{C}$ & $0.5-1.4$ \\
\hline $\mathrm{Fe}_{2} \mathrm{O}_{3}$ & $0.2-0.8$ & $\mathrm{~S}$ & $0.1-0.4$ \\
\hline $\mathrm{CaO}$ & $0.1-0.5$ & Loss of Ignition & $0.7-2.5$ \\
\hline
\end{tabular}




\subsubsection{RECYCLED CONCRETE AGGREGATE}

Table - 2.2 Properties of RCA

\begin{tabular}{|c|c|c|c|c|c|c|c|}
\hline $\begin{array}{l}\text { Sl } \\
\text { no }\end{array}$ & Properties & $\begin{array}{c}0 \% \mathrm{RCA}+ \\
100 \% \\
\mathrm{NCA}\end{array}$ & $\begin{array}{c}10 \% \text { RCA } \\
+ \\
90 \% \mathrm{NCA}\end{array}$ & $\begin{array}{c}20 \% \\
\mathrm{RCA} \\
+ \\
80 \% \\
\mathrm{NCA}\end{array}$ & $\begin{array}{c}30 \% \\
\text { RCA } \\
+ \\
70 \% \\
\text { NCA }\end{array}$ & $\begin{array}{c}40 \% \\
\text { RCA } \\
+ \\
60 \% \\
\text { NCA }\end{array}$ & $\begin{array}{c}50 \% \\
\mathrm{RCA} \\
+ \\
50 \% \\
\mathrm{NCA}\end{array}$ \\
\hline 1 & $\begin{array}{l}\text { Specific } \\
\text { gravity }\end{array}$ & 2.81 & 2.85 & 2.70 & 2.85 & 3.05 & 3.27 \\
\hline 2 & $\begin{array}{l}\text { Impact value } \\
\text { in percentage }\end{array}$ & 16 & 20.8 & 21 & 22 & 22.7 & 23.6 \\
\hline 3 & $\begin{array}{c}\text { Los Angeles } \\
\text { Abrasion } \\
\text { value in } \\
\text { percentage }\end{array}$ & 28.5 & 29 & 29.5 & 29.7 & 30.6 & 31.4 \\
\hline 4 & $\begin{array}{l}\text { Aggregate } \\
\text { Crushing } \\
\text { Value }\end{array}$ & 28.25 & 29 & 29.3 & 29.8 & 32 & 33.25 \\
\hline
\end{tabular}

\subsubsection{WATER ABSORPTION FOR (NCA \& RCA)}

For Natural Coarse Aggregate $=9.8 \%$

For Recycled Concrete Aggregate $=12.7 \%$
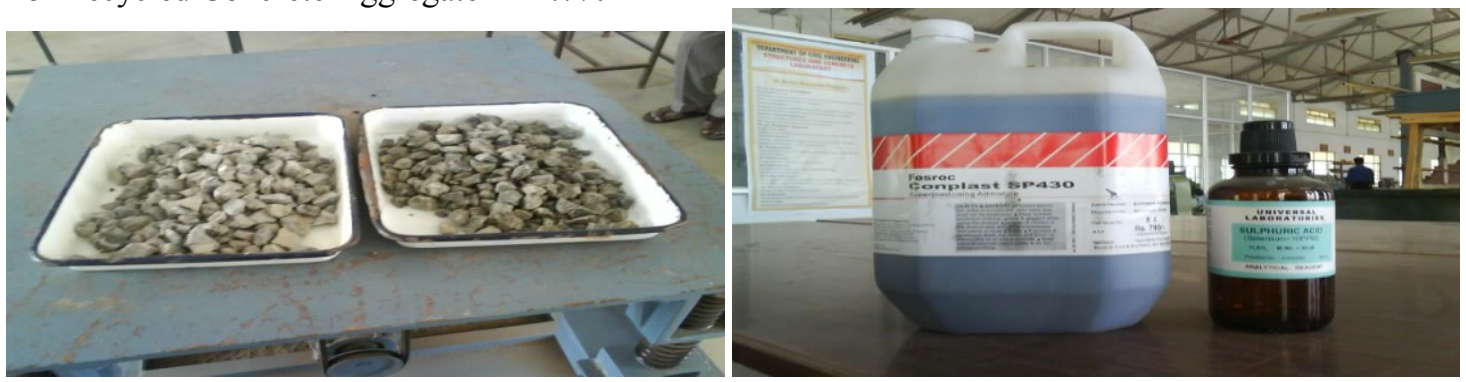

Fig.2.1 RCA, NCA, Super Plasticizer \& Sulphuric acid

\subsubsection{SUPER PLASTICIZER}

Super plasticizer used in this investigation is Conplast SP430 which is Sulphonated Naphthalene polymer based one and supplied as a brown liquid instantly dispersible in water.

Table 2.3 Properties of Super Plasticizer

\begin{tabular}{|c|c|}
\hline Form & Liquid \\
\hline Color & Brown \\
\hline Specific gravity & 1.23 \\
\hline Chloride content & Nil \\
\hline Solid content & 0.48 \\
\hline
\end{tabular}

\subsection{PROPORTIONING}

\subsubsection{TRIAL MIX PROPORTIONS}

Trial mixes were obtained by replacing natural coarse aggregate by replaced coarse aggregate at a replacement level of $10 \%, 20 \%, 30 \%, 40 \%$ and $50 \%$. They are designated as $\mathrm{TM}_{1}, \mathrm{TM}_{2}, \mathrm{TM}_{3}, \mathrm{TM}_{4}, \mathrm{TM}_{5}$ and $\mathrm{TM}_{6}$. The compressive strength of various trial mixes are given in the Table 2.7

Table 2.4 Compressive Strength of Various Trial Mixes

\begin{tabular}{|c|c|c|c|c|c|c|}
\hline Trial mix & TM1 & TM2 & TM3 & TM4 & TM5 & TM6 \\
\hline$\%$ of RCA & 0 & 10 & 20 & 30 & 40 & 50 \\
\hline $\begin{array}{c}7 \text { days } \\
\text { (MPa) }\end{array}$ & 26 & 24.2 & 23.97 & 23.23 & 21.75 & 20.02 \\
\hline $\begin{array}{c}28 \text { days(M } \\
\text { Pa) }\end{array}$ & 49 & 48.62 & 48.02 & 47.77 & 46.2 & 44.1 \\
\hline
\end{tabular}

From the Table it is found that $30 \%$ of natural aggregate can be replaced by recycled aggregate. 
Hence in this thesis all the mixes contain 30\% of Recycled Concrete Aggregate (RCA) and $70 \%$ of natural coarse aggregate.

The following specimens are cast to study the mechanical properties of conventional and recycled concrete.

Table 2.5 Specimens Details

\begin{tabular}{|c|c|c|c|c|c|}
\hline $\begin{array}{l}\text { S. } \\
\text { No }\end{array}$ & $\begin{array}{l}\text { Properties } \\
\text { Studied }\end{array}$ & $\begin{array}{l}\text { Specimen's } \\
\text { Shape }\end{array}$ & $\begin{array}{l}\text { Properties } \\
\text { Studied }\end{array}$ & $\begin{array}{ll}\text { No. } & \text { of } \\
\text { Specimens }\end{array}$ & $\begin{array}{l}\text { Specimens } \\
\text { Size in mm }\end{array}$ \\
\hline 1 & \multirow{3}{*}{$\begin{array}{l}\text { Concrete } \\
\text { Strength } \\
\text { Properties }\end{array}$} & Cube & $\begin{array}{l}\text { Compressive } \\
\text { Strength }\end{array}$ & $3 \times 5 \times 15=225$ & $150 \times 150 \times 150$ \\
\hline 2 & & Prism & $\begin{array}{l}\text { Flexural } \\
\text { Strength }\end{array}$ & $3 \times 5 \times 3=45$ & $100 \times 100 \times 500$ \\
\hline 3 & & Cylinder & $\begin{array}{l}\text { Split Tensile } \\
\text { Strength }\end{array}$ & $3 \times 5 \times 6=90$ & $150 \times 300$ \\
\hline 4 & $\begin{array}{ll}\text { Test } & \text { on } \\
\text { Beams } & \end{array}$ & Rectangle & $\begin{array}{l}\text { Flexural } \\
\text { Strength }\end{array}$ & $3 \times 2=6$ & $\begin{array}{l}100 \times 200 \times 200 \\
0\end{array}$ \\
\hline
\end{tabular}

\subsection{EXPERIMENTAL PROGRAMME}

\subsubsection{PARAMETERS STUDIED}

The experiments are conducted on five series of test specimens. The following properties were studied for all the three grades of concrete.

Mechanical Properties

$\checkmark$ Compressive strength of concrete - cubes

$\checkmark$ Compressive strength of concrete - cylinders

$\checkmark$ Split tensile strength of concrete - cylinders

$\checkmark \quad$ Flexural strength of concrete - beams

\section{Durability Studies}

$\checkmark$ Modified Sorptivity

$\checkmark$ Sulphate Resistance

$\checkmark \quad$ Chloride Resistance

\subsubsection{DESCRIPTION OF TEST PROGRAMME}

\subsubsection{WORKABILITY}

The workability is defined as the property of concrete which determines the amount of useful internal work necessary to produce full compaction.

\subsubsection{MEASURMENT OF WORKABILITY}

The following tests are commonly employed to measure workability.

* Slump cone test

* Compacting factor test

\subsubsection{SLUMP CONE TEST}

Slump cone test is the most commonly used method of measuring consistency. It doesn't measure all factors contributing to workability; it is used as a control test and gives an indication of uniformity of batches. The addition of super plasticizer gives workability to the concrete mix. The obtained test result for various percentage of replacement of RCA with different percentage of Super plasticizer for different mixes is shown in Table 2.6.

Table- 2.6 Slump Cone Test Results

\begin{tabular}{|c|c|c|c|c|}
\hline \multicolumn{2}{|c|}{ Mix } & M I & M II & M III \\
\hline Fly ash (\%) & Super plasticizer (\%) & Slump in mm & Slump in mm & Slump in mm \\
\hline $\mathbf{0}$ & 1.25 & 30 & 28 & 28 \\
\hline $\mathbf{1 0}$ & 1.25 & 28 & 30 & 27 \\
\hline $\mathbf{1 2 . 5}$ & 1.50 & 27 & 29 & 30 \\
\hline $\mathbf{1 5}$ & 2.00 & 24 & 25 & 23 \\
\hline $\mathbf{1 7 . 5}$ & 2.50 & 26 & 29 & 28 \\
\hline
\end{tabular}

\subsubsection{Compacting Factor Test}

Compacting factor test is more precise and sensitive than the slump cone test. This test gives an idea for degree of compaction and adopted to find the workability of concrete where aggregate size does not exceed 
$20 \mathrm{~mm}$ and the mixes are comparatively dry. The obtained test results for various percentage of fly ash, for different mixes are shown in Table2.7.

Table- 2.7 Compacting Factor Test Result

\begin{tabular}{|c|c|c|c|c|}
\hline \multicolumn{2}{|c|}{ MIX } & M I & M II & M III \\
\hline Silica Fume (\%) & $\begin{array}{c}\text { Super plasticizer } \\
(\%)\end{array}$ & \multicolumn{3}{|c|}{ Compacting Factor } \\
\hline 0 & 1.25 & 0.97 & 0.96 & 0.94 \\
\hline 10 & 1.25 & 0.95 & 0.95 & 0.96 \\
\hline 12.5 & 1.50 & 0.97 & 0.97 & 0.98 \\
\hline 15 & 2.00 & 0.95 & 0.98 & 0.98 \\
\hline 17.5 & 2.50 & 0.95 & 0.94 & 0.97 \\
\hline
\end{tabular}

The compacting factor test results given in Table 2.7 shows that as the percentage of super plasticizer increases, the compaction factor increases. It also shows that the addition of super plasticizer enhance more workability to the mix which it is added.

\subsubsection{Compressive Strength of Cylinder}

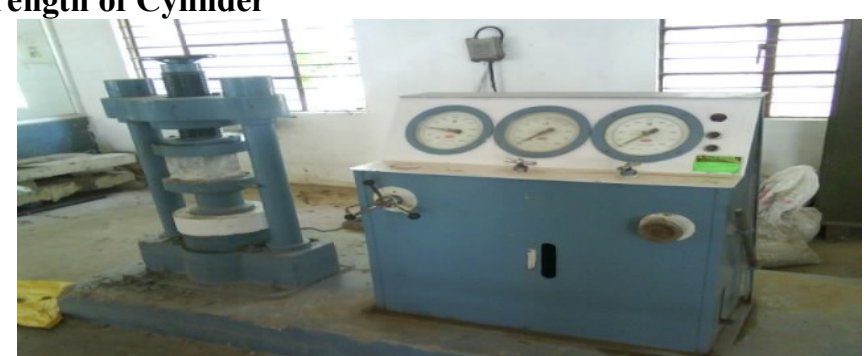

Fig 2.2 Compressive Strength of Cylinder \& Cube

\subsubsection{Split Tensile Strength of Cylinder}

The cylindrical specimens of size $150 \mathrm{~mm}$ x $300 \mathrm{~mm}$ are used to determine the split tensile strength as per IS: $516-1959$. Typical test setup for testing split tensile strength of cylinder is shown in Figure 2.3

Splitting tensile strength $=2 \mathrm{P} / \pi D L$

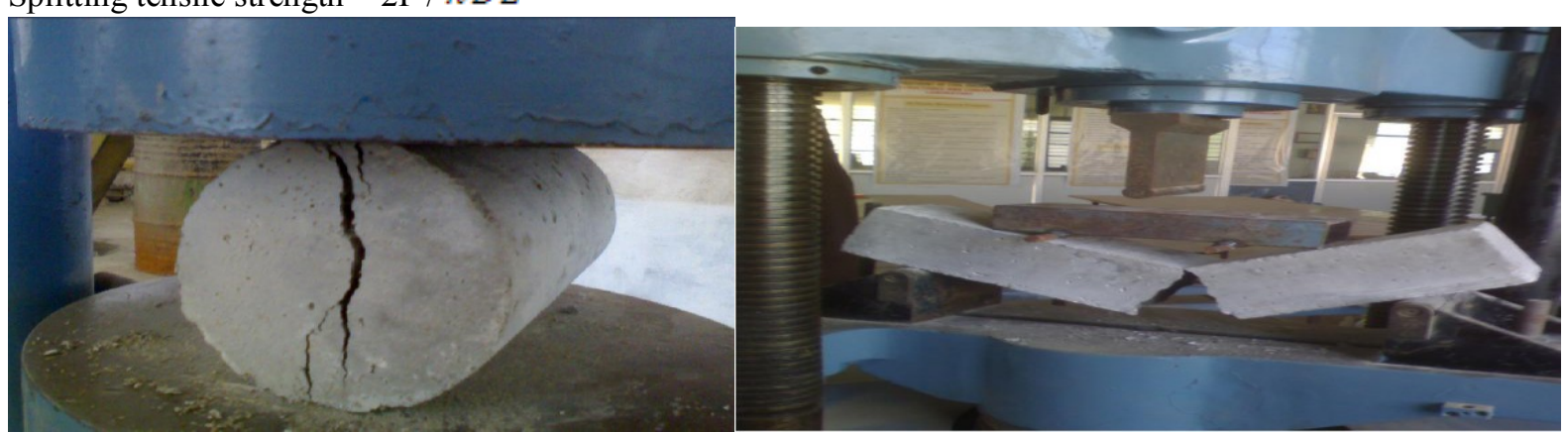

Fig 2.3 Split Tensile Strength of Cylinder \& Flexural Strength of Beams

\subsubsection{Flexural Strength of Beams} capacity.

Flexural Strength $\quad \mathrm{F}_{\mathrm{f}}=\mathrm{PL} / \mathrm{BD}^{2}$

$\mathrm{P}=$ max load in $\mathrm{N}$ applied to specimen

$\mathrm{L}=$ length in $\mathrm{mm}$ of span as which specimen was supported.

$\mathrm{B}=$ measured width of specimen in $\mathrm{mm}$

$\mathrm{D}=$ measured depth of specimen in $\mathrm{mm}]$

\subsection{Design of Flexure beam}

The beam can be broadly divided into two regions. In region-I (section 1-1), the bending moment is less than the cracking moment $\left(\mathrm{M}_{\mathrm{r}}\right)$ of the section with the result that every section in this region remains fully un cracked and the complete section is effective in resisting bending moment, Therefore, the moment of inertia I of the section for deflection calculations is I - the moment of inertia of concrete gross cross - section or of the transformed gross section. 


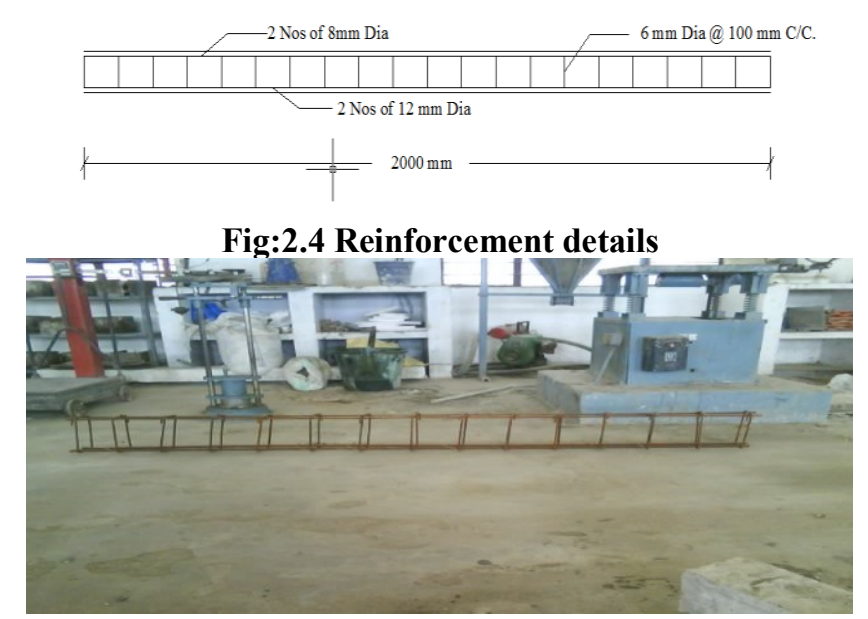

Fig 2.5Reinforcement for Flexure Beam

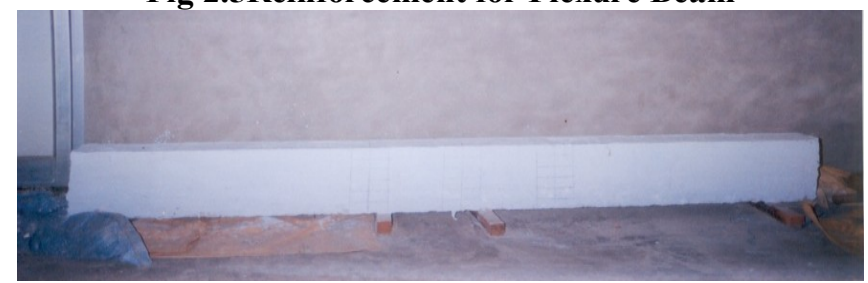

Fig 2.6 Beam after casting

\subsection{EXPERIMENTAL SET UP}

These beams were tested on a span of $1500 \mathrm{~mm}$ with simply supported conditions under two point loading. Deflections were measured under the loading point and at the mid span using Linear Variable Differential Transducers (LVDTs). The crack patterns were also recorded at every load increment. All the beams were tested up to failure.

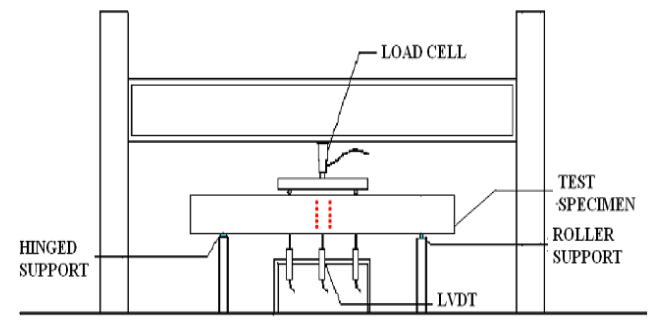

Fig 2.7 The Schematic Diagram Of Loading Set-Up

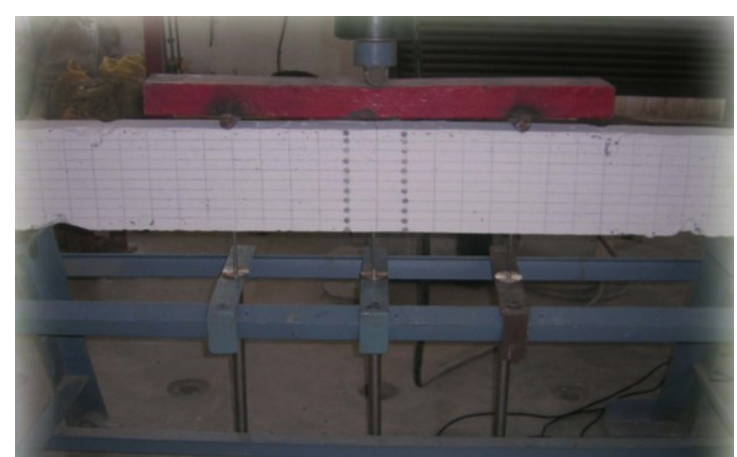

Fig 2.8 Arrangement of Pivots for Strain Measurement and LVDTs for Deflection Measurement 


\subsection{TEST RESULTS AND DISCUSSION}

Table 2.8 Cube Compressive Strength for M I Mix

\begin{tabular}{|c|c|c|c|c|c|}
\hline $\begin{array}{c}\text { Silica Fume } \\
(\%)\end{array}$ & $\begin{array}{c}7 \text { days } \\
(\mathrm{MPa})\end{array}$ & $\begin{array}{c}\text { 14days } \\
(\mathrm{MPa})\end{array}$ & $\begin{array}{c}28 \text { days } \\
(\mathrm{MPa})\end{array}$ & $\begin{array}{c}56 \text { days } \\
(\mathrm{MPa})\end{array}$ & $\begin{array}{c}90 \text { days } \\
(\mathrm{MPa})\end{array}$ \\
\hline $\mathrm{C}$ & 30.8 & 37.2 & 47.77 & 49.6 & 52.22 \\
\hline 10 & 29.74 & 37.9 & 47.98 & 50.85 & 53.7 \\
\hline 12.5 & 32.96 & 40.45 & 49.94 & 52.43 & 55.5 \\
\hline 15 & 30.42 & 36.03 & 46.8 & 48.9 & 52.4 \\
\hline 17.5 & 20.16 & 35.76 & 44.7 & 46.84 & 49.2 \\
\hline
\end{tabular}

Table 2.9 Cube Compressive Strength for M II Mix

\begin{tabular}{|l|l|l|l|l|l|}
\hline $\begin{array}{l}\text { Silica } \\
\text { Fume }(\%)\end{array}$ & $\begin{array}{l}7 \text { days } \\
(\mathrm{MPa})\end{array}$ & $\begin{array}{l}14 \text { days } \\
(\mathrm{MPa})\end{array}$ & $\begin{array}{l}28 \text { days } \\
(\mathrm{MPa})\end{array}$ & $\begin{array}{l}56 \text { days } \\
(\mathrm{MPa})\end{array}$ & $\begin{array}{l}90 \text { days } \\
(\mathrm{MPa})\end{array}$ \\
\hline C & 27.72 & 33.26 & 42.65 & 44.8 & 46.92 \\
\hline 10 & 28.8 & 36.1 & 45.12 & 47.8 & 50.6 \\
\hline 12.5 & 30.4 & 36.8 & 46.1 & 49.3 & 51.2 \\
\hline 15 & 29.58 & 34.4 & 44.16 & 46.8 & 49.6 \\
\hline 17.5 & 26.78 & 32.2 & 41.87 & 43.9 & 46.12 \\
\hline
\end{tabular}

Table 2.10 Cube Compressive Strength for M III Mix

\begin{tabular}{|c|c|c|c|c|c|}
\hline $\begin{array}{c}\text { Silica Fume } \\
(\%)\end{array}$ & $\begin{array}{c}7 \text { days } \\
(\mathrm{MPa})\end{array}$ & $\begin{array}{c}14 \text { days } \\
(\mathrm{MPa})\end{array}$ & $\begin{array}{c}28 \text { days } \\
(\mathrm{MPa})\end{array}$ & $\begin{array}{c}56 \text { days } \\
(\mathrm{MPa})\end{array}$ & $\begin{array}{c}90 \text { days } \\
(\mathrm{MPa})\end{array}$ \\
\hline $\mathrm{C}$ & 25.89 & 32.5 & 41.12 & 43.17 & 45.23 \\
\hline 10 & 20.3 & 34.3 & 42.9 & 45.5 & 48.3 \\
\hline 12.5 & 30 & 34.5 & 44.2 & 46.8 & 49.2 \\
\hline 15 & 21.3 & 33.3 & 42.1 & 44.6 & 47.3 \\
\hline 17.5 & 20.3 & 31.2 & 39.5 & 41.4 & 44.2 \\
\hline
\end{tabular}

2.8.1.1 Graphical results for Compressive Strength of cube

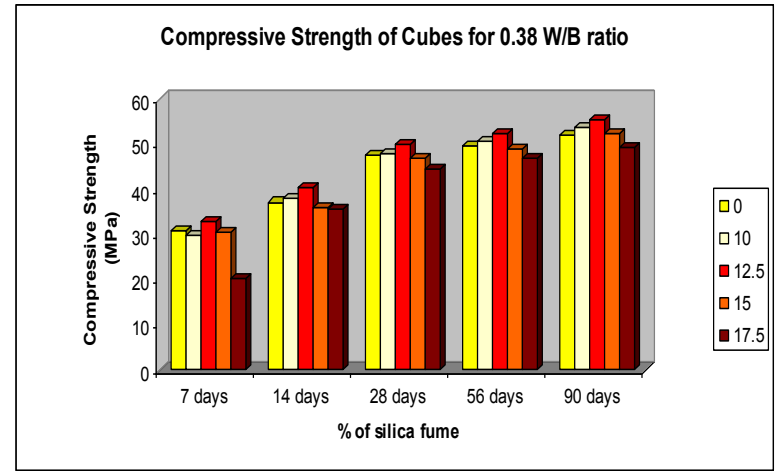

Fig 2.9 Cube Compressive Strength for M I Mix

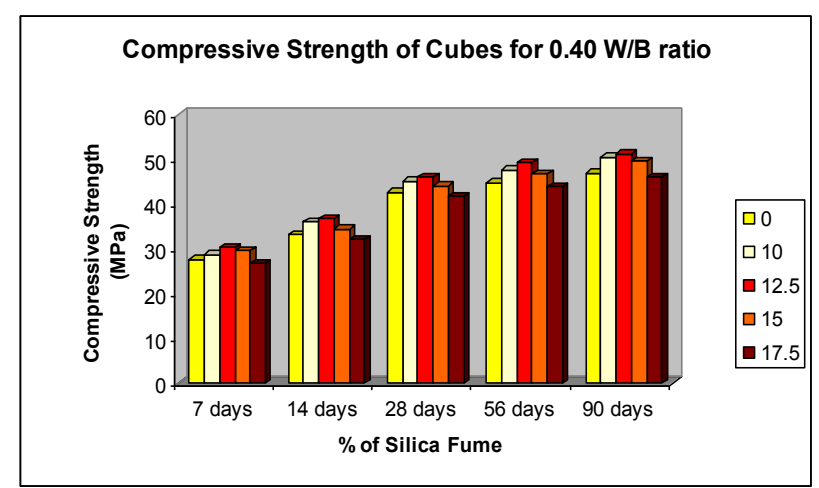

Fig 2.10 Cube Compressive Strength for M II Mix 


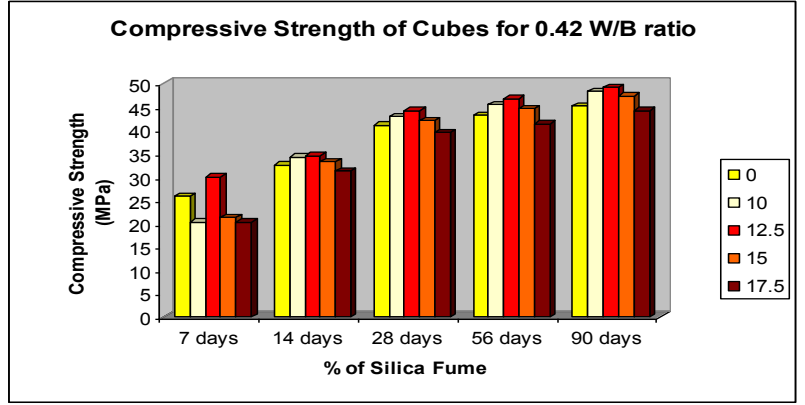

Fig 2.11 Cube Compressive Strength for M III Mix

Graphical results for compressive strength of cube for M I, M II \& M III

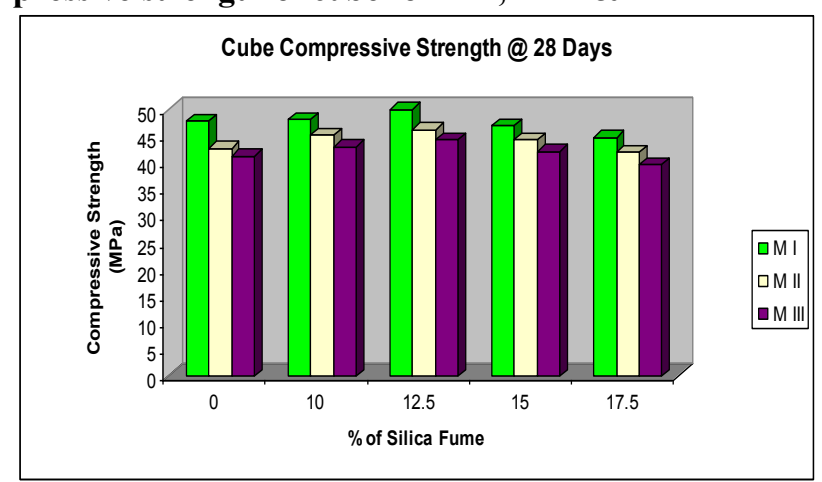

Fig 2.12 Cube Compressive Strength for 28 days

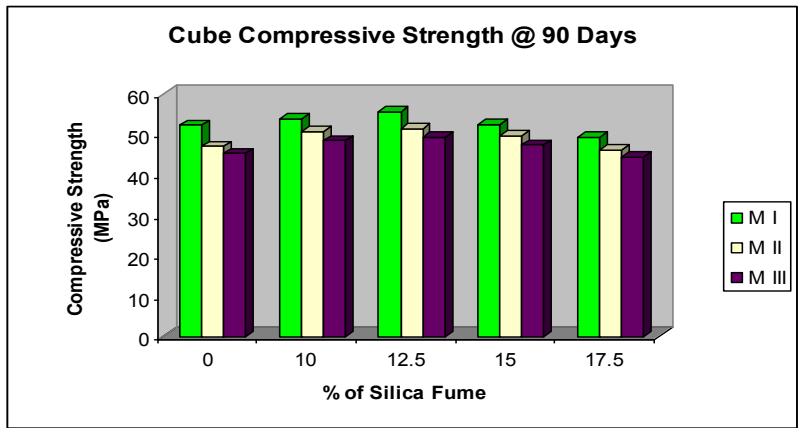

Fig 2.13 Cube Compressive Strength for 90 days

From the above results it is observed that the strength increases with the age of curing and strength increase with increase in the Silica Fume content up to $12.5 \%$ replacement by $2-10 \%$ and there after increase in Silica Fume reduced the compressive strength by $4-17 \%$ when compared with control mix. With increase in the water content compressive strength reduced by $5-13 \%$

\subsubsection{Compressive strength of cylinder}

The average compressive strength of cylinder obtained is shown below in the Table.

Table 2.11 28 Days Cylinder Compressive Strength for M I Mix

\begin{tabular}{|c|c|c|c|}
\hline \multirow{2}{*}{$\begin{array}{l}\text { Silica Fume in } \\
(\mathbf{\%})\end{array}$} & \multicolumn{3}{|c|}{ Compressive Strength in MPa } \\
\cline { 2 - 4 } & MI & MII & MIII \\
\hline 0 & 41.5 & 40.9 & 38.7 \\
\hline 10 & 38.9 & 37.6 & 36.7 \\
\hline 12.5 & 40.4 & 38.5 & 37.8 \\
\hline 15 & 37.5 & 36.2 & 35.4 \\
\hline 17.5 & 35.8 & 33.5 & 32.6 \\
\hline
\end{tabular}

\section{Graphical results for Compressive Strength of Cylinders}




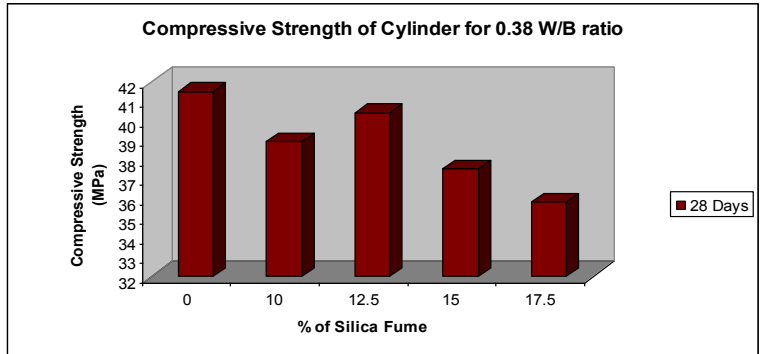

Fig 2.14 Cylinder Compressive Strength for M I Mix

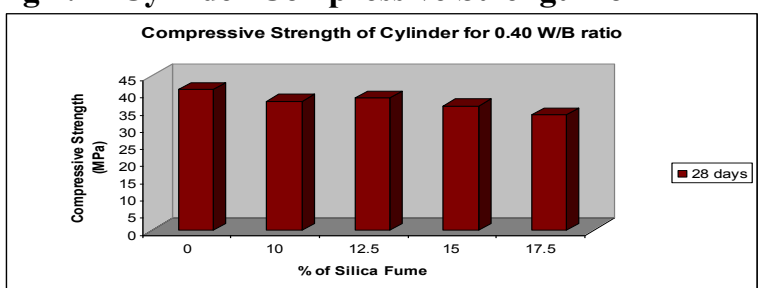

Fig 2.15 Cylinder Compressive Strength for M II Mix

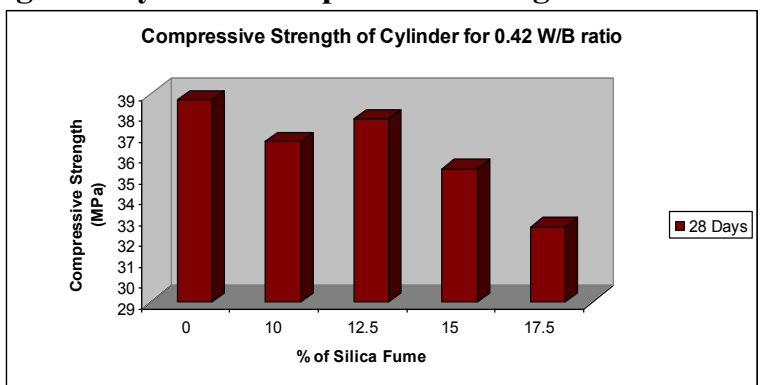

Fig 2.16 Cylinder Compressive Strength for M III Mix

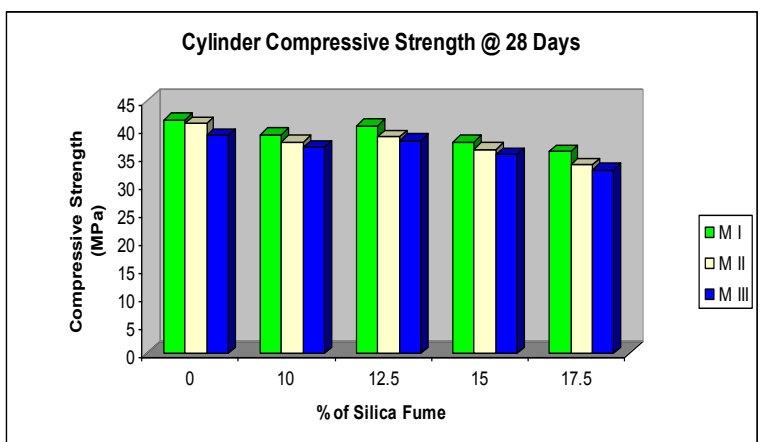

Fig 2.17Cylinder Compressive Strength for M I, MII, MIII Mix

From the above results it is observed that the compressive strength of concrete mixes containing Silica Fume increased up to $12.5 \%$ replacement by $3-6 \%$ and there after increase in Silica Fume reduced by $15-27 \%$ when compared with control mix. With increase in the water content compressive strength reduced by $5-13 \%$

Table 2.12 28 Days Split Tensile strength for M I Mix

\begin{tabular}{|c|c|c|c|}
\hline $\begin{array}{c}\text { \% of Silica } \\
\text { Fume }\end{array}$ & \multicolumn{3}{|c|}{ 28 Days Strength (MPa) } \\
\hline & MI & MII & MIII \\
\hline 0 & 3.89 & 3.72 & 3.47 \\
\hline 10 & 3.87 & 3.47 & 3.45 \\
\hline 12.5 & 3.81 & 3.52 & 3.4 \\
\hline 15 & 3.66 & 3.25 & 3.2 \\
\hline 17.5 & 3.57 & 3.12 & 3.02 \\
\hline
\end{tabular}




\section{Graphical results for split tensile strength}

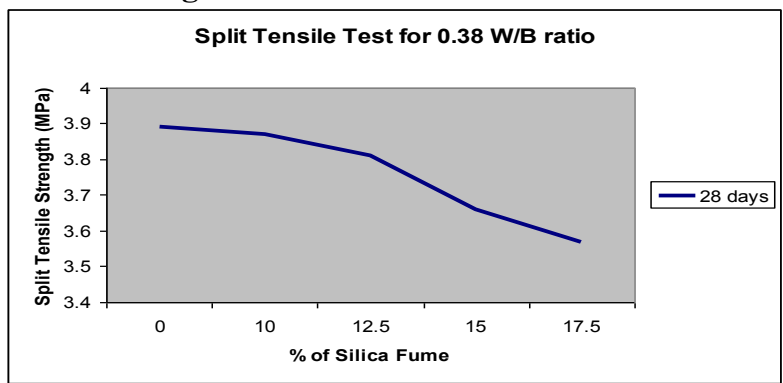

Fig 2.18Split Tensile Strength for M I Mix

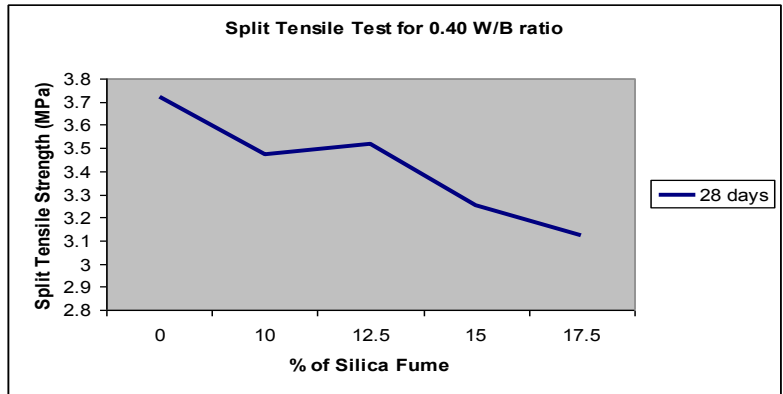

Fig 2.19Split Tensile Strength for M II Mix

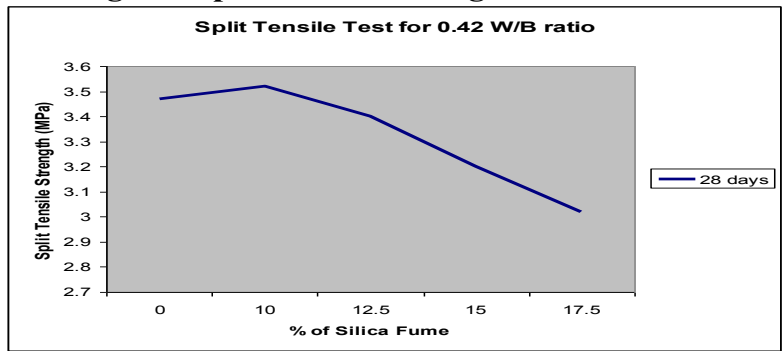

Fig 2.20 Split Tensile Strength for M III Mix

Graphical results for Split Tensile strength of cylinders for M I, M II, M III.

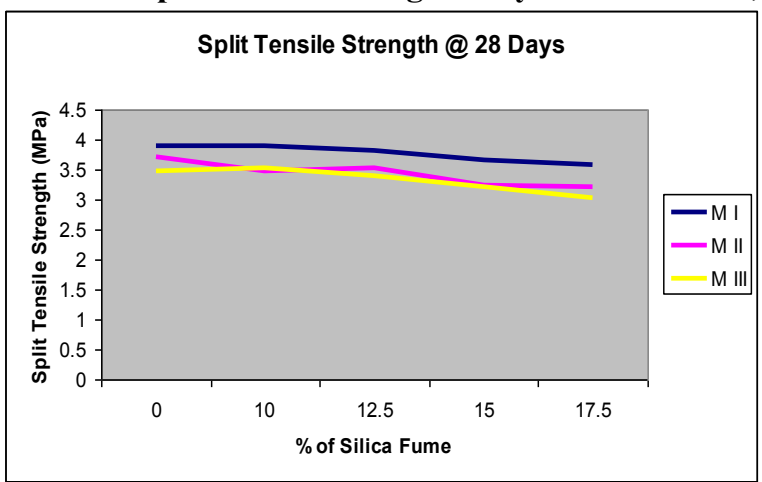

Fig 2.21 Split Tensile Strength for Various Mixes

From the results it is observed that the Split Tensile strength of concrete mixes containing Silica Fume increased up to $12.5 \%$ replacement by $2-7.5 \%$ and there after increase in Silica Fume reduced by $9-20 \%$ when compared with control mix. With increase in the water content split tensile strength reduced by $8-14 \%$

\subsubsection{Flexural Strength of beams}

The modulus of rupture test is conducted on beam of size $100 \times 100 \times 500 \mathrm{~mm}$ after a curing period of 28 days with the help of universal testing machine (UTM) of $400 \mathrm{KN}$ capacity. 
Table 2.13 28 Days Flexural strength for M I Mix

\begin{tabular}{|c|c|c|c|c|}
\hline & \multirow{2}{*}{$\begin{array}{c}\text { \% of Silica } \\
\text { Fume }\end{array}$} & \multicolumn{3}{|c|}{ 28 Days Strength (MPa) } \\
\cline { 3 - 5 } & M1 & MII & MIII \\
\hline 10 & 0 & 5.05 & 4.61 & 4.41 \\
\hline 12.5 & 10 & 4.81 & 4.62 & 4.52 \\
\hline 15 & 15 & 4.86 & 4.7 & 4.6 \\
\hline 17.5 & 17.5 & 4.51 & 4.4 & 4.38 \\
\hline
\end{tabular}

Graphical results for Flexural Strength of beams

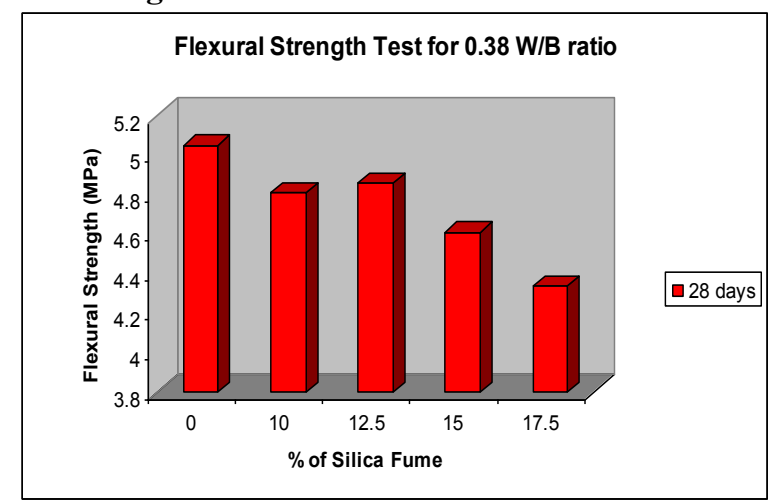

Fig 2.22 Flexural Strength for M I Mix

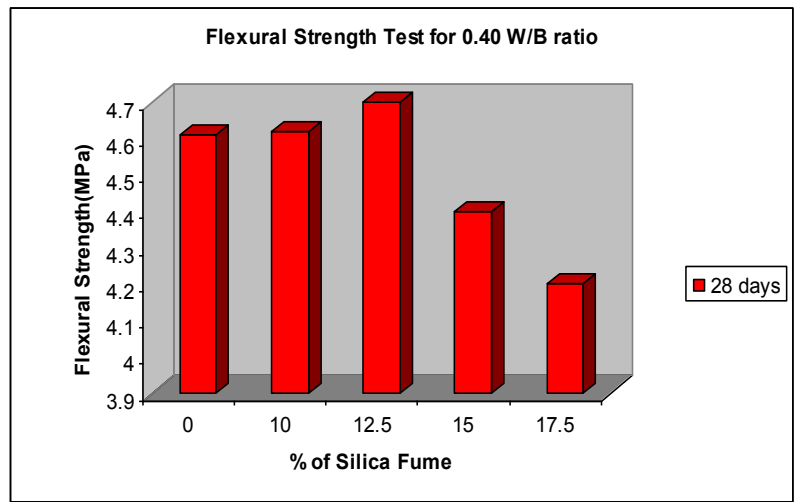

Fig 2.23 Flexural Strength for M II Mix

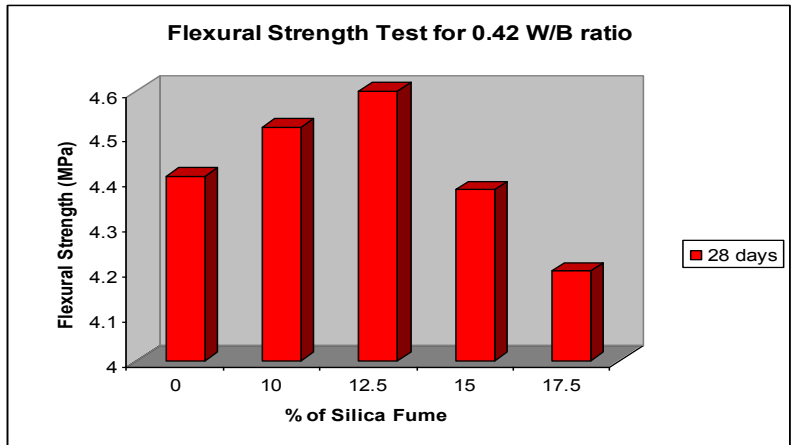

Fig 2.24 Flexural Strength for M III Mix

Graphical results for Flexural strength of beam for M I, M II, M III. 


\subsubsection{Flexural Beam}

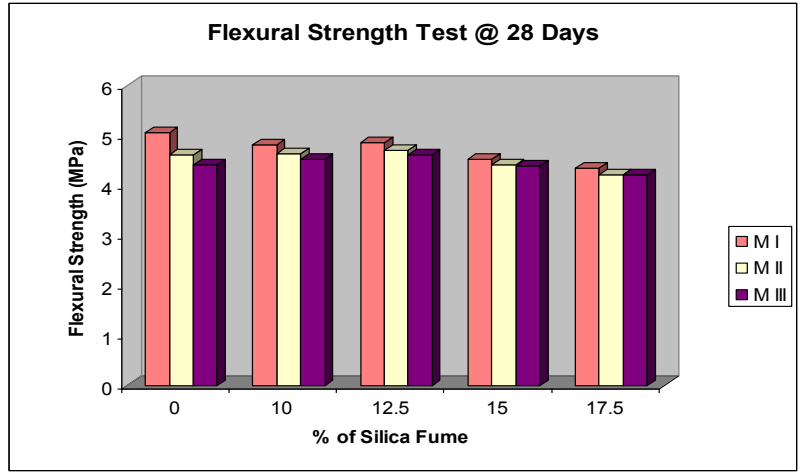

Fig 2.25 Flexural Strength for Various Mixes

Table 2.14 - Flexural Test Results for Beam Specimen

\begin{tabular}{|l|l|l|l|l|}
\hline $\begin{array}{l}\text { Description } \\
\text { of test } \\
\text { specimens }\end{array}$ & $\begin{array}{l}\text { \%o of } \\
\text { Silica Fume }\end{array}$ & $\begin{array}{l}\text { First Crack } \\
\text { load } \\
(\mathbf{k N})\end{array}$ & $\begin{array}{l}\text { Ultimate } \\
\text { Load } \\
(\mathbf{k N})\end{array}$ & $\begin{array}{l}\text { Deflection at } \\
\text { Ultimate } \\
\text { Load (mm) }\end{array}$ \\
\hline 0.38 Control & 0 & 28 & 49 & 18 \\
\hline $\begin{array}{l}0.38 \text { Silica } \\
\text { Fume }\end{array}$ & 12.5 & 33 & 60 & 19.46 \\
\hline 0.40 Control & 0 & 26 & 48 & 21.3 \\
\hline $\begin{array}{l}0.40 \text { Silica } \\
\text { Fume }\end{array}$ & 12.5 & 29 & 54 & 22.75 \\
\hline 0.42 Control & 0 & 23 & 44 & 22.67 \\
\hline $\begin{array}{l}0.42 \text { Silica } \\
\text { Fume }\end{array}$ & 12.5 & 27 & 51 & 22 \\
\hline
\end{tabular}

Comparison of First Crack Load and Ultimate

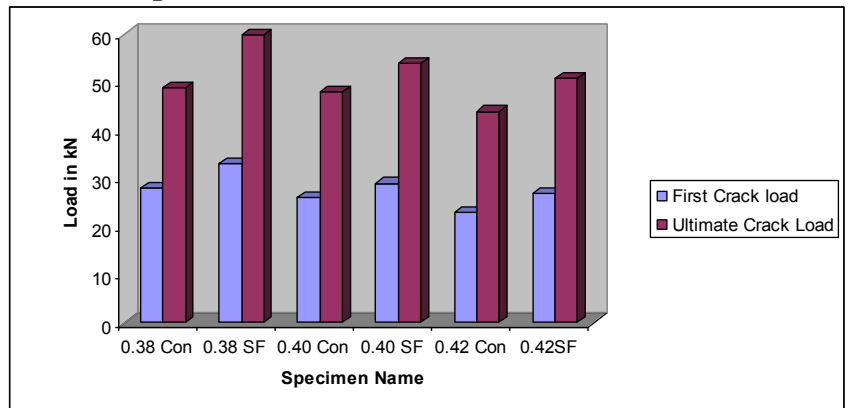

Fig 2.26 Comparison of First Crack Load and Ultimate Load

\subsubsection{Load versus Deflection $(P-\Delta)$ Curves}

Load versus Deflection curves for the beam specimen tested for Flexure are Shown below. Comparison of (P- $\Delta$ ) curves for beam specimens 0.38 Control, 0.38 SF, 0.40 Control, 0.40 SF, 0.42 Control, 0.42 SF are shown below.

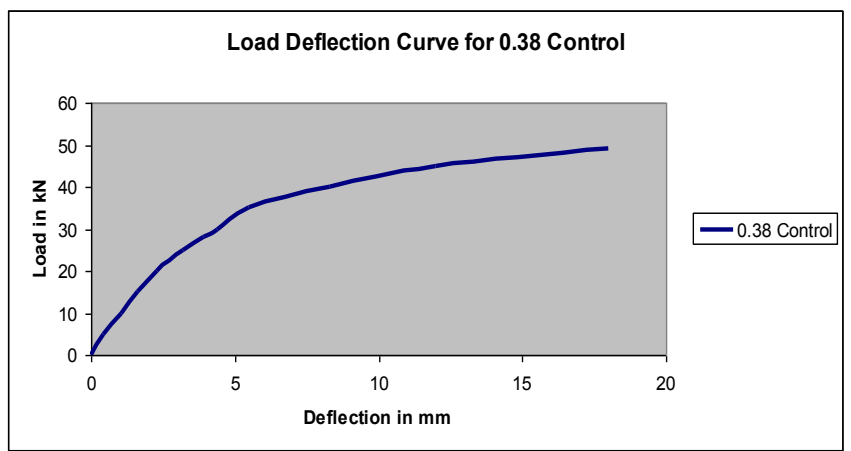

Fig 2.27 Load Vs Deflection for 0.38 Control Mix 


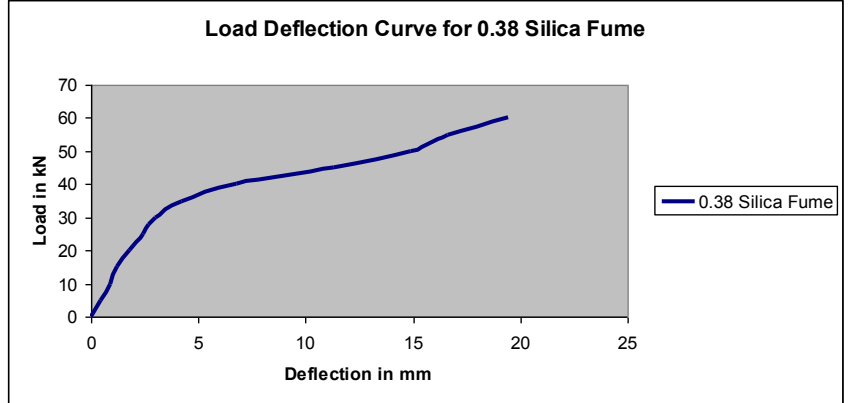

Fig 2.28 Load Vs Deflection for 0.38 Silica Fume Mix

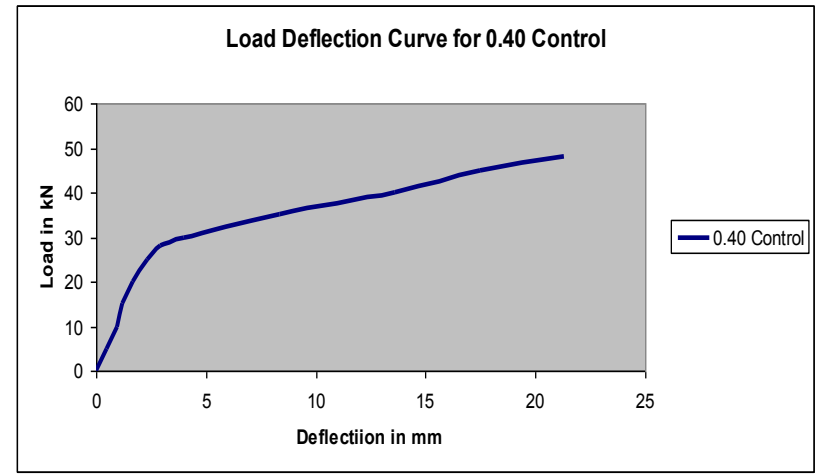

Fig 2.29 Load Vs Deflection for 0.40 Control Mix

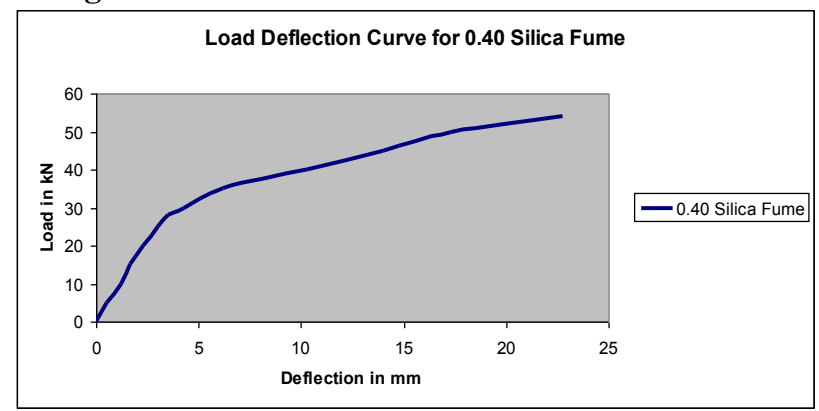

Fig 2.30 Load Vs Deflection for 0.40 Silica Fume Mix

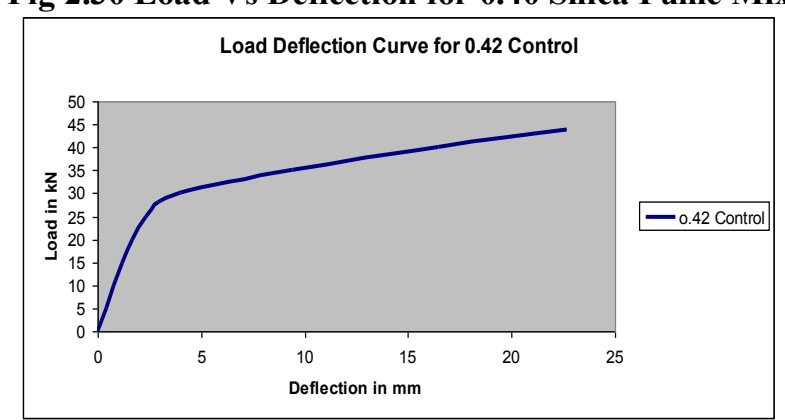

Fig 2.31 Load Vs Deflection for 0.42 Control Mix

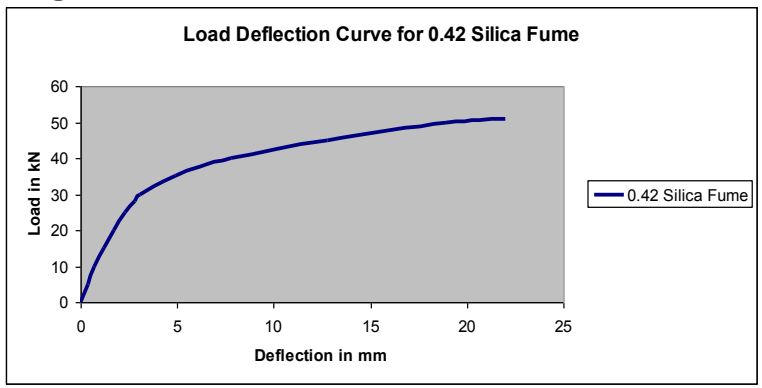

Fig 2.32 Load Vs Deflection for 0.42 Silica Fume 

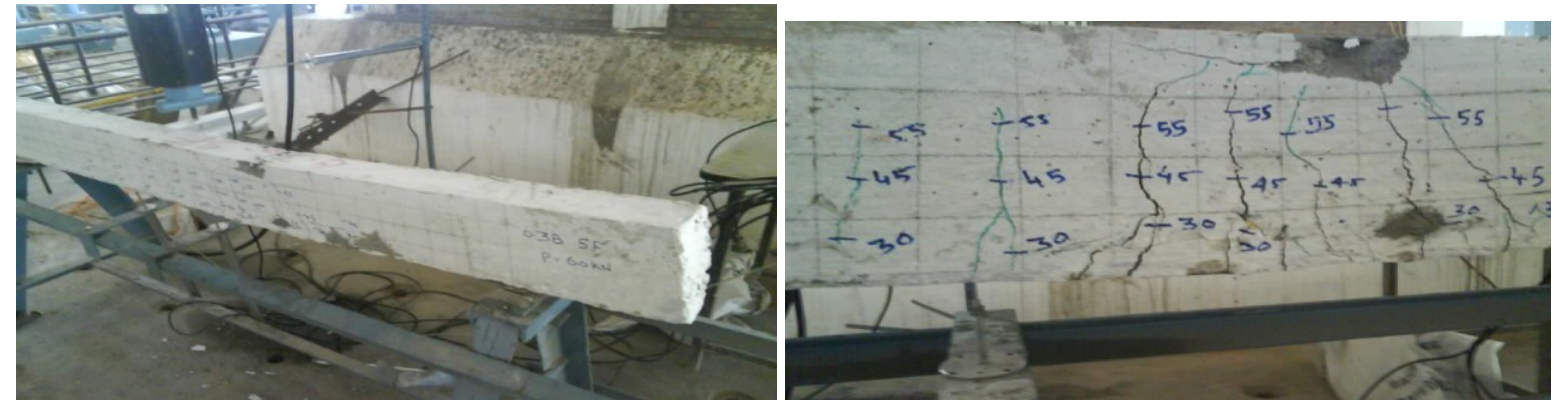

Fig 2.33 Crack Pattern of Flexural Beam

\section{Reference}

[1]. IS: 383-1970, "specification for coarse and fine aggregate from natural sources for concrete", Bureau of Indian standards, New Delhi.

[2]. 2.Shetty, M.S (2001) "Concrete technology theory and practice", Chand and company.

[3]. T. S. Nagaraj and ZahidaBonn (1996): "Efficient utilization of rock dust and pebbles as aggregates in Portland cement concrete". The Indian concrete journal, Vol No1.53-56, January.

[4]. International journal of Advance in Civil Engineering, vol 1 (1-2) jan - dec 2011.

[5]. International journal of Sustainable Civil Engineering, vol 3 No.1 jan - jun 2011 